THE IMPLEMENTATION OF TEACHING STRATEGY IN CONDUCTING SPEAKING SKILL FOR GRADE X AT SMA NEGERI 1 BADAR

\author{
AN ARTICLE \\ Submitted in Partial Fulfillment of the Requirement for \\ the Degree of Sarjana Pendidikan
}

By

NAOMI YOHANNA TRI NANDA

Reg. Number: 2133321026

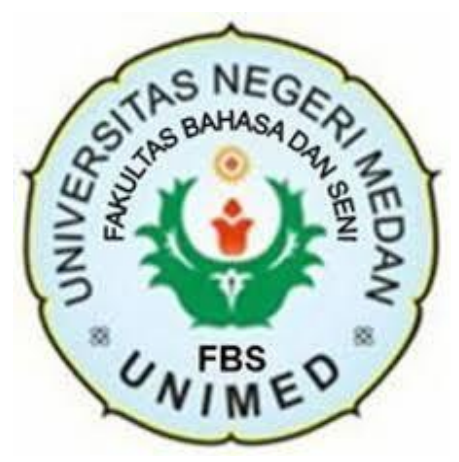

ENGLISH AND LITERATURE DEPARTMENT

FACULTY OF LANGUAGES AND ARTS

STATE UNIVERSITY OF MEDAN

2018 
ARTIKEL

\section{THE IMPLEMENTATION OF TEACHING STRATEGY IN CONDUCTING SPEAKING SKILL FOR GRADE X AT SMA NEGERI 1 BADAR}

Disusun dan Diajukan oleh:

Naomi Yohanna Tri Nanda NIM. 2133321026

Telah diverifikasi dan dinyatakan memenuhi syarat

untuk diunggah pada jurnal online

Medan, Oktober 2018

Menyetujui

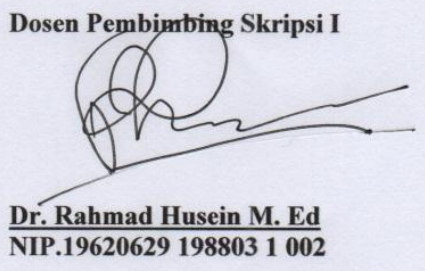

Dosen Pembimbing Skripsi II

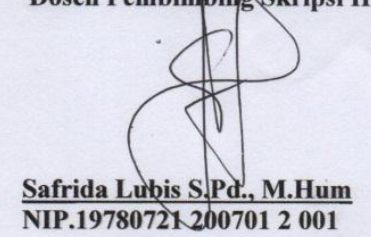

Ka. Program Studi

Pendidikan Bahasa Inggris

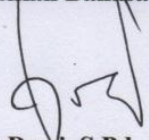

Nora Ronita Dewi, S.Pd., S.S., M.Hum.

NIP. 198005222008122003 


\title{
THE IMPLEMENTATION OF TEACHING STRATEGY IN CONDUCTING SPEAKING SKILL FOR GRADE X AT SMA NEGERI 1 BADAR
}

\author{
*Naomi Yohanna Tri Nanda \\ ** Dr. Rahmad Husein, M.Ed. \\ **Safrida Lubis, S.Pd., M.Hum.
}

\begin{abstract}
This study aims to find strategies on teaching English Speaking which are suitable to the needs of students of Senior High School. The research was conducted by descriptive qualitative research through three phases; observation, interviewing and documentation. It was conducted in SMA Negeri 1 Badar, especially grade X. The data were gathered by administering interview and observation to 20 respondents to get the students' needs. The interview and observation results prove that the teaching strategy is not implemented well and need to be improved. The average scores are the first from English lecturer and the second from English teacher. It means that the implementation of teaching strategy in conducting speaking skill as suitable or approriate for grade X of SMA Negeri 1 Badar.
\end{abstract}

Key words: Descriptive Qualitative Reseach, Speaking Skill, Curriculum 2013.

\author{
*Graduate \\ ** Lecturer
}




\section{INTRODUCTION}

\section{Background of The Study}

English has become a primary language of communication. It is spoken by millions of people all over the world. It has become a dominant language in many fields of activity, such as industry, military, business, tourism, transportation, sports, international relations, etc. Besides, English language also covers abilities of language. One of them is speaking ability.

Speaking is a process to convey and to share ideas and feeling orally. It involves some skills such as accuracy, appropriateness, fluency, and vocabulary building. It is a crucial part of second language learning and teaching so that we need to practice it in our educational environment, especially in an English lesson. Despite its importance, for many years, teaching speaking has been undervalued and English language teachers have continued to teach speaking just as a repetition of drills or memorization of dialogues. Students' speaking ability were relatively low compared to another abilities which teacher has been thought.

Based on my observation during In Service Training Program, I see that students have difficulties on learning speaking. The teacher tended to use explanation and discussion as the activities. When the observer did the interview to some students, it was found that the methods used by the teacher made them bored and sleepy. Even though the students could communicate with their friends during the discussion activity, they felt that they did not get enough time to practice their speaking.

The variety of classroom activities to engage students' involvement is also lacking. Considering their age, the students are in a transition stage between children and adults. Psychology wise, they possess a lot of energy and are in need of attention from peers. Considering this into account, designing various activities that offer interactions among the students can be helpful to get students involved and engaged in the teaching and learning process which will in return increase the chance of achieving teaching objectives.

Students are expected to take action and be able to adjust and put themselves in accordance with their competence. The schools build the student's potential that they have. Students need conditions to conduct experiment and explore according to their talents and interests. Undang-Undang RI Nomor 20 Tahun 2003 tentang Sistem Pendidikan Nasional Pasal 1 butir 1 stated that:

Education is a conscious and deliberate effort to create an atmosphere of learning and the learning process so that learners are actively developing the 
potential for them to have the spiritual power of religion, self-control, personality, intelligence, character, and skills needed by themselves, society, nation and state.

The learning process related with curriculum used. The curriculum contains guidelines of learning programs that accepted by students. Subjects, competencies, teacher methods, and assessments technique will be drawn in the curriculum. According to Undang-Undang RI Nomor 20 Tahun 2003 tentang Sistem Pendidikan Nasional Pasal 1 butir 19, curriculum is a set of plans and arrangements regarding the objectives, content and learning materials as well as the methods used to guide the implementation of learning activities to achieve specific educational objectives.

Curriculum 2013 views that the knowledge cannot be moved away from the teacher to the students. Students are subjects to actively search for, cultivate, construct, and use knowledge. Therefore, learning process should give opportunity for students to construct knowledge in cognitive processes. In order to understand and apply the knowledge, students should work and solve problems and strive to realize their ideas. Curriculum 2013 design students to learn independently, multitasking, searching for study materials from various sources, find and analyse problems that exist through a model of scientific learning that is expected to create individual who are critical, disciplined, responsible, work hard, and never give up. Curriculum 2013 is expected to make Indonesian productive, creative, innovative, and affective through the integration of attitudes, skills and knowledges.

Curriculum 2013 uses authentic assessment in assessing the learning outcomes of students. Curriculum 2013 is a set of learning activities that promotes scientific approach to observe, ask, train, try, associate, and communicate. Teachers are required to be a professional teacher as a facilitator in the learning process.

\section{REVIEW OF LITERATURE}

Speaking is the process of building and sharing meaning through the use of verbal and non-verbal symbols, in a variety of contexts (Chaney, 1998:13). Speaking is a skill used by someone in daily life communication whether at school or outside. Speaking is a productive skill which involves the speaker to use speech to express meanings to other people (Spratt, Pulverness, and Williams, 2005). Another definition is proposed by Harmer (2007: 343). 
Harmer $(2001: 275)$ points out three different roles that the teacher needs to play to get students speak fluently. The first role is as a prompter. Sometimes, when students are involved in a role-play activity, for example, they are get lost, do not know about what they are going to say next, or they forget for words. In this situation, it is natural that the teacher wants to help the students and acts as a prompter. The second role is as a participant. Back then, teachers do not participate and give feedback to the student while they are doing a group discussion or role play.

According to Brown (2001), the students at this age are in the phase of transition, confusion, self-consciousness, growing, and changing bodies and minds. It is the challenge for the teacher. The teacher should understand that the students in the age are between childhood and adulthood. Therefore, they need a very special set of consideration applied to teach them.

\section{RESEARCH METHODOLOGY}

This research was a descriptive qualitative research since the data were collected in the form of words or pictures rather than numbers. Parse (2001: 57) states that the purpose of the descriptive qualitative method is to study a phenomenon to discover the patterns and themes about life events. It is used when the researcher has a specific question about the phenomenon. Descriptive qualitative method is used for research which is focused on social connections, interrelationships, life events, and other matters concerned with social sciences.

The subject of this research is students which are in grade X of SMA Negeri 1 Badar. I am interested in doing an observation and interview at SMA Negeri 1 Badar is to find out whether the problems on the implementation of 2013 Curriculum also occur there.

Moleong (2001: 121) states that in qualitative research, the researcher plays an important role as the designer, data collector, analyst, data interpreter, and reporter of the research finding. The main instrument in this research was the researcher.

\section{TECHNIQUE OF DATA COLLECTION AND ANALYSIS}

In this stage, the researcher carried out some activities that can be used to find out the field problems. First, a classroom observation on Apr 28th 2018 was conducted to gather the information about the English teaching and learning process in class X SMA Negeri 1 Badar. The researcher came to the classroom 
and observed the English teacher in delivering the English materials to the students.

Second, some interviews were also done by the researcher on Apr 28th, 2018. The researcher interviewed the students in order to collect data about the students' perspective on the English class. Then, to find out the weaknesses as well as the suggestions related to the English teaching and learning process, the researcher did an interview with the English teacher.

After conducting classroom observation and interview, on Apr 28th 2018, the researcher checked the lesson plan and the assisting book. In this case the school used handbook from the government.

After deciding the field problems to solve, the researcher analyzed the field problems and the main causes. Regarding the selected field problems, there were three factors which affected the problems. Those were the students, the media and the activities in English teaching and learning process.

The first factor was related to the media. Media which can be used to attract students' attention was absent. This condition made the students got bored easily. Moreover, the materials used were only from the handbook which was less various. It made the students less interesting because the exercises in the handbook did not provide enough activities for the students to speak.

The second factor was related to the activities in teaching and learning process. Based on the classroom observation, the teacher tended to dominate the classroom. Almost all of the time, the students were listening to the teacher's explanation. Although there was a listen and repeat activity, it did not give enough time for the students to practice their English.

Furthermore, since most of the activities were taken from the handbook, they were likely to be individual tasks. The activities focuses more on writing and reading that make the students' opportunities to practice their speaking skills were rare.

The researcher did teacher's interview to find out if there were more specific problem about the implementation of teaching startegy. Questions created to find out what was the usual activity that the teacher used in teaching speaking, how was the teaching and learning process, why the teacher used the strategy, is there any difficulties in teaching and learning process and the last was the solution to the problems found while doing that strategy. 
After doing the interview (see Appendix B), the researcher found out some problems that affected the teaching process. First, as the teacher answered question about the usual strategy implemented in class was discussion, dialogue practice and describing something. This strategy was quite monotonous if the teacher couldn't find the interesting or fun materials. The teacher also said that this strategy helped students the most because it could help the students to interact with another students. This was effective to made the students active and interested in doing speaking.

The researcher found that this strategy was so general, this might used alot in every meeting of speaking class so the students might get bored and sleepy. This strategy also wasn't effective because students who were active in class kept answering the teacher's question but the other students kept silent and didn't really enjoy the learning process.

The researcher did interview to two students to found if there were problem in learning and practicing speaking. There were problems found, they were grammar, pronunciation, and vocabulary.

The first problem was grammar. The student confused if she was asked to speak English because she couldn't arrange the word to made good sentences. The students should be motivated a lot to speak English in class even if they were wrong. As we know that speaking English was not easy, we had to practice a lot day by day to make it better.

Second problem found was vocabulary. Lack of vocabulary was the most general problem found for all students because not all students used to speak English daily and they didn't hear or see people speaking in English. They also didn't try to memorize or searching for English words. Back at the basic problem, that it was still less motivation for students to practice their speaking skill. They also like to others friend who try to speak English and that was the reason there were to shy in speaking English.

\section{CONCLUSIONS AND SUGGESTIONS}

\section{CONCLUSIONS}

The research held on April 28th, 2018. This study aims to know if the implementation of teaching strategy affects students motivation to improve the students' speaking skill.Based on the findings on Chapter IV, it can be seen that there was a few problems in the teacher's teaching strategy. The conclusions of the research can be concluded as follows. 
1. The implementation of teaching strategy didn't going as the lesson plan goal. There were two main reasons that make the strategy didn't running well. First, the teacher ran the clas activity monotonously. There were less speaking activity in the class. The students didnt have an intention to be involved in class acitvity. Second, the students willingness to study also low.

2. The teaching process didn't go as the 2013 Curicullum goals. There were some of steps that didn't work in the teaching process.

\section{SUGGESTIONS}

Based on the findings, conclusions of the implementation of teaching strategy in conducting speaking skill in grade X SMA N 1 Badar, the researcher wants to suggest some points to some parties. The suggestions are presented as follows.

\section{To English teachers}

There are a lot of strategies to teach spaking skill for example role play. It can help to motivate them in learning speaking English. Therefore, it is suggested to the English teachers to use role play as an activity in the classroom. Fun activities like role play will help the teacher to engage the students in the English teaching and learning process.

However, a teacher of English needs to enrich herself with the knowledge of how to select the effective resources that can improve the students' motivation toward the lesson. By creating effective and interesting activities, the teacher could make the student enjoy the English teaching and learning process better.

\section{To students}

The students should manage themselves to always have positive attitudes towards English lesson. They should have high motivation in learning English, especially speaking. They should understand that it is very important for them to have more practices in speaking English. It is because vocabulary mastery and pronunciation can be improved through practicing. Moreover, they should continuously be active during the English teaching and learning process.

\section{To other researchers}

It is suggested that the other researchers can use the result of this study as a reference. It is also advisable to conduct further research on this matter since this research is still far from perfect. 


\section{REFERENCES}

Brown, H. Douglas. 2001. Teaching by Principles: An Interactive Approach to Language Pedagogy. New York: Pearson Education.

Harmer, J. (1998). How to teach English. Person: Longman.

Spratt, Pulverness, and William.(2005). The TKT (Teaching Knowledge Test)

Course. Cambridge: Cambridge University Press. 